\title{
DESAIN RESEARCH: PENERAPAN PENDEKATAN PMRI KONSEP LUAS PERMUKAAN DAN VOLUM KERUCUT UNTUK MENINGKATKAN KEMAMPUAN PEMECAHAN MASALAH MATEMATIS
}

\author{
(RESEARCH DESIGN: \\ IMPLEMENTATION OF PMRI APPROACH IN TEACHING CONE'S \\ SURFACE AREA AND VOLUME TO IMPROVE MATH PROBLEM- \\ SOLVING ABILITY)
}

\author{
Rizal Kamsurya ${ }^{1}$ \\ ${ }^{1}$ STKIP Media Nusantara Citra, rizal_kamsurya@stkipmnc.ac.id
}

\begin{abstract}
Abstrak
Pendekatan PMRI sebagai salah satu pendekatan yang berorientasi pada aktivitas siswa memberikan kesempatan kepada siswa untuk menemukan konsep berdasarkan pengalaman yang diperoleh dari dunia nyata. Penelitian ini bertujuan untuk mengetahui penerapan pendekatan PMRI pada pembelajaran luas permukaan dan volum kerucut untuk meningkatkan kemampuan pemecahan masalah matematis. Penelitian ini menggunakan metode design research dengan tiga tahap yaitu persiapan, eksperimen mengajar, dan analisis retrospektif. Penelitian terdiri dari 4 pertemuan dengan subjek penelitian 6 orang. Instrumen yang digunakan yaitu tes kemampuan pemecahan masalah, observasi, wawancara, rekaman suara, dan hipotesis lintasan belajar. Hasil analisis retrospektif menunjukkan bahwa penerapan pendekatan PMRI dengan menggunakan konteks "kukusang" dan "kagepe" mampu meningkatkan aktivitas dan pemahaman siswa terhadap materi luas permukaan dan volum kerucut, serta kemampuan pemecahan masalah matematis siswa. Hasil analisis data menunjukkan bahwa terdapat peningkatan kemampuan siswa dalam menyelesaikan soal pemecahan masalah disertai dengan tahapan penyelesaiannya.
\end{abstract}

Kata kunci: PMRI, Pemecahan Masalah Matematis, "Kukusang," "Kagepe"

\begin{abstract}
PMRI (the Indonesian version of realistic mathematics education) approach as one of approach which is students' activities orientation gives full opportunity to the student in discovering the concept based on their own experience that they attain real world through learning activities inside the classroom. The aim of this research is to identify the implementation of PMRI approach in teaching cone's surface area and volume to improve math problem-solving ability. This research is applying research design methodology that contains three stages that are preparing, teaching experiment and retrospective analysis. The research is deploying four meetings with research subject are six students. The research instruments in collecting data are summative test of problem-solving ability, observation, interviews, sound recording, and cross-learning hypothesis. The retrospective analysis results shows that the implementation of PMRI approach by using "kukusang" and "kagepe" context can improve students'
\end{abstract}


activity and comprehension in learning cone's surface area and volume as well as the math problem-solving ability. Data analysis results describes that there is a significant progress of students' ability in answering problemsolving question along with stages of completion.

Keywords: PMRI, Math problem-solving, "Kukusang”, "Kagepe”

\section{PENDAHULUAN}

Tujuan pembelajaran matematika di SMP yaitu memahami konsep matematika, mengembangkan penalaran matematis, mengembangkan kemampuan memecahkan masalah, mengembangkan kemampuan komunikasi matematis, dan mengembangkan sikap menghargai matematika (Wardhani, 2008). Oleh karena itu, siswa perlu dilatih untuk memecahkan masalah matematika, sehingga nantinya mampu berpikir sistematis, logis dan kritis dalam memecahkan masalah kehidupan yang dihadapinya.

Kegiatan pembelajaran matematika tentu tidak akan terlepas dari masalah matematika. Masalah bagi siswa dalam pembelajaran matematika adalah persoalan atau soal (Abidin, 2015: 49). Kemampuan pemecahan masalah memiliki keterkaitan dengan tahap menyelesaikan masalah matematika. Menurut Neimark terdapat lima langkah dalam kegiatan pemecahan masalah yaitu penemuan masalah (problem finding), perumusan masalah (stating the problem), perencanaan solusi (planning a solutions), pelaksanaan rencana (acting on the plan), dan evaluasi (Floyd: 2002). Sejalan dengan pendapat Neimark, tahap pemecahan masalah matematika yaitu memahami masalah, membuat rencana penyelesaian, melaksanakan rencana, dan melihat kembali (Polya: 1973).

Sejak tahun 2000, Indonesia telah ikut berpartisipasi dalam Programme for International Student Assessment (PISA). PISA merupakan suatu program penilaian skala internasional untuk mengukur kemampuan membaca, matematika, dan sains siswa sekolah berusia 15 tahun (OECD, 2003). PISA bertujuan untuk mengetahui sejauh mana siswa bisa menerapkan pengetahuan yang sudah dipelajari di sekolah dalam kehidupan sehari-hari dan dalam berbagai situasi. Di dalam soal matematika PISA, terdapat delapan ciri kemampuan kognitif matematika, yaitu thinking and reasoning, argumentation, communication, modeling, problem posing and solving, representation and using symbolic, formal and technical language and operations, use of aids and tools. Kedelapan komponen kognitif tersebut sangat sesuai dengan tujuan pembelajaran matematika yang tercantum dalam Lampiran Permendiknas Nomor 22 Tahun 2006 tentang Standar Isi (Evy Yosita Silva, Zulkardi, dan Darmawijoyo, 2011: 2), yaitu (1) memahami konsep matematika, menjelaskan keterkaitan antar konsep dan mengaplikasikan konsep atau algoritma secara luwes, akurat, efisien dan tepat 4 dalam pemecahan masalah, (2) menggunakan penalaran pada pola dan sifat, melakukan manipulasi matematika dalam membuat generalisasi, menyusun bukti atau menjelaskan gagasan dalam pernyataan matematika, (3) memecahkan masalah yang meliputi kemampuan memahami masalah, merancang model matematika, menyelesaikan model dan menafsirkan solusi yang diperoleh, (4) mengomunikasikan gagasan dengan simbol, tabel, diagram, atau media lain untuk menjelaskan keadaan atau masalah, (5) memiliki sikap menghargai kegunaan matematika dalam kehidupan, yaitu memiliki rasa ingin tahu, perhatian dan minat dalam mempelajari matematika, serta sikap ulet dan percaya diri dalam 
memecahkan masalah. Berdasarkan hal tersebut, maka hasil PISA pada bidang matematika dapat digunakan untuk mengetahui sejauh mana kualitas pembelajaran matematika di sekolah. Melihat begitu pentingnya pemecahan masalah dalam pembelajaran matematika, maka diharapkan oleh guru untuk dapat mencari solusi yang tepat dalam mengatasi permasalahan tersebut. Pemecahan masalah selain sebagai salah satu tujuan belajar, pemecahan masalah juga menjadi tujuan utama dalam belajar matematika.

Solusi untuk mengatasi masalah di atas, salah satunya adalah dengan menerapkan pendekatan Pendidikan Matematika Realistik Indonesia (PMRI). Pendekatan PMRI merupakan salah satu pendekatan yang berorientasi pada aktivitas siswa dalam proses pembelajaran di kelas. PMRI memberikan kesempatan sepenuhnya kepada siswa untuk menemukan konsep pembelajaran berdasarkan pengalaman yang diperoleh dari dunia nyata melalui aktivitas dalam pembelajaran di kelas. Penerapan pendekatan PMRI dalam proses pembelajaran juga didukung dengan hasil penelitian yang dilakukan oleh Nurshanti dengan menerapkan pendekatan PMRI pada siswa kelas VIII SMP Negeri 121 Jakarta, diperoleh bahwa penerapan pendekatan PMRI dalam proses pembelajaran mampu meningkatkan kemampuan pemecahan masalah matematis khususnya dalam pembelajaran luas permukaan kubus dan balok (Nurshanti, 2016).

Bangun ruang sisi lengkung khususnya pada sub pokok bahasan kerucut merupakan salah satu materi yang sangat berkaitan erat dengan kehidupan siswa. Terdapat banyak benda memiliki bentuk menyerupai kerucut yang dapat ditemukan dalam kehidupan sehari-hari diantaranya adalah ice cream, terompet, topi ulang tahun, "kukusang", dan sebagainya. "Kukusang" sebagai alat untuk mengukus "kasuami" yang terbuat dari anyaman daun kelapa, sehingga memiliki bentuk yang menyerupai kerucut. Sedangkan "kasuami" merupakan salah satu makanan pokok masyarakat yang bersuku Buton dan berbahan baku utama dari singkong (ketela pohon atau ubi kayu) yang diparut kemudian dikukus dan dibentuk seperti tumpeng atau gunungan berbentuk kerucut. Bahan dasar inilah yang disebut "kagepe".

"Kukusang" sebagai alat untuk memasak "kasuami" merupakan salah satu pengetahuan yang telah lama melekat dalam diri siswa di SMP Negeri 11 Seram Barat, karena merupakan bahan makanan pokok yang selalu dikonsumsi setiap hari sehingga membuka potensi pedagogis dengan mempertimbangkan pengetahuan para siswa yang diperoleh dari belajar di luar kelas. Pengetahuan yang telah dimiliki oleh siswa dapat menjadi sumber belajar jika dapat dimanfaatkan dengan maksimal. Keterkaitan antara pembelajaran matematika dengan "kukusang" yakni terletak pada bentuk "kukusang" itu sendiri. Biasanya masyarakat setempat yang tanpa disadari dalam membuat "kukusang" menggunakan pengetahuan geometri. Hal ini dikarenakan dalam bentuk badan "kukusang" yang akan dibuat selalu berbentuk kerucut. Hal ini tentunya dapat dimanfaatkan sebagai salah satu sumber pembelajaran matematika yang mana pendekatan PMRI menggunakan konteks dunia nyata sebagai salah satu objek dalam pembelajarannya. 


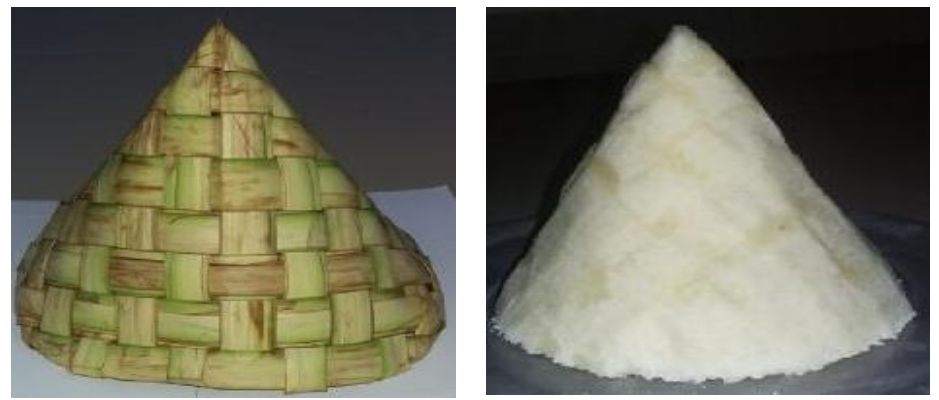

Gambar 1. "Kukusang” dan "Kasuami”

\section{KAJIAN TEORI}

\section{Pendekatan PMRI}

Pendekatan PMRI merupakan pembelajaran matematika di sekolah yang bertitik tolak dari hal-hal real bagi kehidupan peserta didik dan memberi kesempatan kepada peserta didik untuk belajar melakukan aktivitas pada pelajaran matematika Pritina (Hasanah et al., 2016). Pendekatan pendidikan matematika realistik merupakan teori pembelajaran yang bertitik tolak dari hal-hal 'real' bagi siswa, menekankan keterampilan 'process of doing mathematics', berdiskusi dan berkolaborasi, berargumentasi dengan teman sekelas sehingga mereka dapat menemukan sendiri ('student inventing' sebagai kebalikan dari 'teacher telling') dan pada akhirnya menggunakan matematika itu untuk menyelesaikan masalah baik individual maupun kelompok (Zulkardi, 2001).

Pembelajaran dengan menggunakan pendekatan PMRI memiliki lima karakteristik yaitu penggunaan konteks, penggunaan model matematika progresif, pemanfaatan hasil konstruksi siswa, interaktivitas, dan memiliki keterkaitan Treffers (Maslihah, 2012). Selain karakteristik, terdapat tiga prinsip utama dalam pendekatan matematika realistik yaitu (1) penemuan terbimbing dan matematisasi progresif; (2) fenomemologi didaktis, dan (3) membangun sendiri model (Gravemeijer, 1994).

\section{Kemampuan Pemecahan Masalah}

Kemampuan pemecahan masalah merupakan bagian yang tak terpisahkan dalam pembelajaran matematika, sehingga harus memperoleh perhatian serius dari para guru (Turmudi, 2008). Pemecahan masalah adalah proses menerapkan pengetahuan yang telah diperoleh sebelumnya ke dalam situasi baru yang belum diketahui (Wardhani, 2010). Kemampuan pemecahan masalah adalah kemampuan menyelesaikan masalah rutin, non-rutin, rutin terapan, non-rutin terapan dan masalah non-rutin non rutin terapan dalam bidang matematika (Lestari dan Yudhanegara, 2015). Berdasarkan berbagai pendapat di atas, maka pemecahan masalah yang dimaksudkan dalam penelitian ini adalah suatu kemampuan untuk menyelesaikan soal-soal non-rutin yang bersumber dari konteks dunia nyata siswa dengan menggunakan kemampuan yang telah dimiliki oleh siswa itu sendiri.

Langkah-langkah pemecahan masalah yang yang digunakan dalam penelitian ini mengikuti langkah-langkah pemecahan masalah yang dikemukakan oleh Polya (2004) yaitu (1) memahami masalah (understanding the problem), (2) Membuat rencana penyelesaian (devising a plan), (3) melaksanakan rencana pemecahan (carryng out the plan), dan (4) melihat kembali. Hal ini dilakukan dengan pertimbangan (1) langkah-langkah dalam proses pemecahan masalah yang dikemukakan oleh Polya cukup sederhana dan mudah, (2) Aktivitas pada setiap 
langkah yang dikemukakan Polya cukup jelas, dan (3) langkah-langkah pemecahan masalah menurut Polya secara implisit mencakup semua tahapan pemecahan masalah menurut para ahli yang lain.

\section{METODE PENELITIAN}

Jenis penelitian yang akan digunakan yakni menggunakan penelitian desain (design research). Menurut Barab dan Squire dalam Van den Akker (2006) penelitian design research merupakan serangkaian pendekatan dengan maksud untuk menghasilkan teori-teori baru, artefak, dan model praktis yang menjelaskan dan berpotensi berdampak pada pembelajaran dengan pengaturan

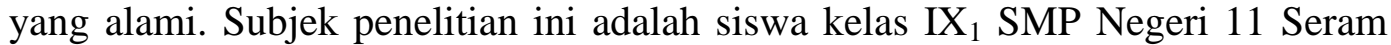
Barat tahun ajaran 2017/2018 berjumlah 6 orang yang dipilih secara purposive sampling dari 28 orang siswa.

Penelitian design research terdiri dari tiga tahapan, yaitu (1) desain permulaan (preliminary design); kegiatan yang dilakukan pada tahapan desain permulaan yakni membuat Hipotesis Lintasan Belajar (HLB) yang merupakan lintasan belajar (proses berpikir), (2) eksperimen (experiment); desain yang telah dibuat diujicobakan kepada siswa pada tahap eksperimen. Uji coba ini bertujuan untuk melihat apakah hal-hal yang sudah diantisipasi dalam tahap desain permulaan (preliminary design) sesuai dengan fakta yang terjadi atau tidak, dan (3) analisis tinjauan; seluruh data yang diperoleh pada tahapan sebelumnya dilakukan analisis pada tahap ini. Instrumen yang digunakan yaitu tes kemampuan pemecahan masalah dan non tes yang terdiri dari observasi, wawancara secara mendalam, dan rekaman suara. Proses analisisnya berupa HLB yang diantisipasi sebelum pembelajaran dan aktivitas yang benar-benar terjadi (Bakker, 2004).

\section{HASIL DAN PEMBAHASAN}

1. Hasil Eksperimen Mengajar

a. Pertemuan Pertama: Menentukan Unsur-Unsur dan Jaring-Jaring Kerucut

Aktivitas yang dilakukan siswa untuk mencapai tujuan pembelajaran tersebut yakni siswa mengidentifikasi berbagai unsur-unsur yang terdapat dalam "kukusang" sehingga dapat membantu siswa dalam menentukan unsur-unsur dan jaring-jaring kerucut. Konteks yang digunakan pada aktivitas pertama adalah "kukusang." "Kukusang" merupakan salah satu benda yang memiliki bentuk menyerupai kerucut dan sangat identik dengan kehidupan siswa sehari-hari, sebab "kukusang" sering digunakan oleh siswa untuk memasak (mengukus) salah satu makanan pokok di daerah setempat yakni "kukusang" sehingga diharapkan dengan menggunakan konteks "kukusang" siswa mampu menentukan unsur-unsur dan jaring-jaring kerucut.

Pembelajaran dilaksanakan dengan guru mulai mengarahkan siswa membuat alas "kukusang" sehingga menjadi sebuah benda yang berbentuk kerucut. Proses mengarahkan pemikiran siswa dilakukan dengan cara mengajukan pertanyaan secara langsung oleh guru sehingga terjadi proses tanya jawab, seperti termuat dalam kutipan wawancara berikut.

Guru : Kamu semua telah menyebutkan bahwa yang kurang dari "kukusang” sehingga dapat dikatakan sebagai sebuah kerucut adalah alasnya. 
Apakah ada yang tahu bagaimana cara untuk membuat alas "kukusang," sehingga alas yang dibuat memiliki ukuran yang sama dengan bagian alas pada "kukusang?"

A3 : Digambar pak guru.

Guru : Digambar seperti apa?

A3 : Digambar di atas kertas, pasti ukurannya sama pak guru.

Guru : Setelah digambar, kemudian gambar tersebut di apakan?

SP 4 : Kan bisa langsung digunting pak guru gambarnya.

Guru : Apakah benar seperti itu?

Siswa : Iya pak guru.

Kutipan hasil wawancara di atas menggambarkan bahwa proses membuat alas "kukusang" sehingga menjadi sebuah kerucut dapat ditentukan dengan baik oleh siswa yakni dengan cara menempelkan "kukusang" pada sebuah kertas dan membuat lingkaran berdasarkan lingkaran pada "kukusang" tersebut, sehingga menghasilkan sebuah alas "kukusang" yang ukuran sama dengan lingkaran alas "kukusang." Hasil dari penggambaran tersebut, kemudian digunting dan ditempelkan pada bagian bawah (alas) "kukusang," hingga menjadi sebuah kerucut yang utuh. Aktivitas proses pembuatan alas "kukusang" terlihat bahwa seluruh siswa pada setiap kelompok tidak mengalami kesulitan yang berarti, karena pemahaman konsep membuat alas telah dipahami dengan baik oleh siswa.
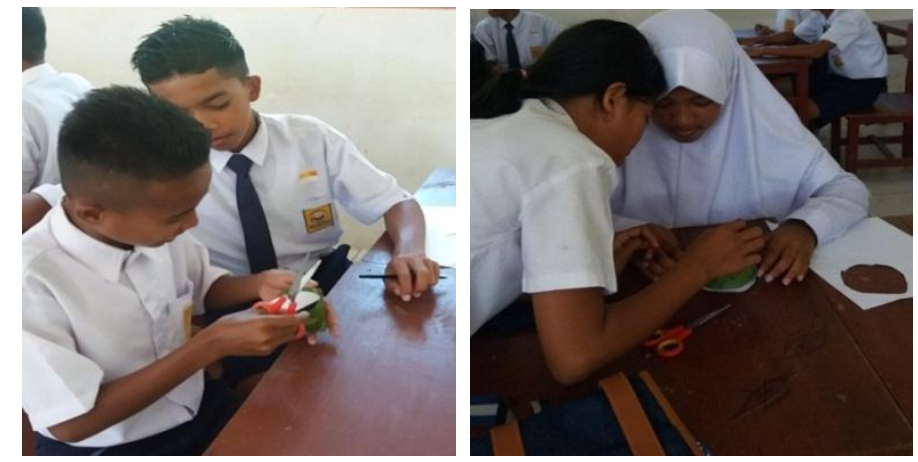

Gambar 2. Aktivitas Siswa dalam Membuat Alas "Kukusang"

Aktivitas membuat alas "kukusang" menunjukkan kreativitas serta kerja sama antara siswa dalam setiap kelompok yang mulai terjalin. Proses pembuatan alas "kukusang" didahulukan dengan diskusi singkat antara siswa dalam kelompok dan bekerja sama untuk saling membantu membuat alas "kukusang" sehingga memiliki ukuran yang sesuai. Ketika setiap kelompok telah mampu membuat alas "kukusang" dengan baik, siswa diarahkan untuk berdiskusi dengan teman kelompoknya untuk menyelesaikan LAS 1.

Selanjutnya, guru mengarahkan siswa untuk membuat garis pelukis pada "kukusang" yang telah ditambahkan alas sebelumnya dengan menggunakan kertas HVS, kemudian menggunting "kukusang" tersebut sehingga berbentuk seperti juring. Aktivitas ini dilakukan agar siswa dapat menemukan dan memahami bahwa "kukusang" yang memiliki bentuk menyerupai kerucut, apabila digunting melalui garis pelukisnya maka akan berbentuk seperti juring pada lingkaran. Aktivitas menggunting "kukusang" seperti tampak pada Gambar 3 berikut. 

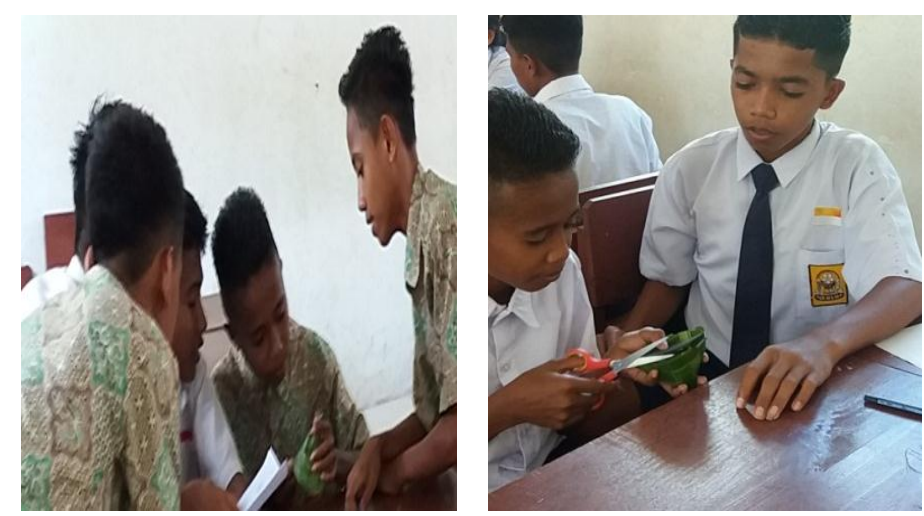

Gambar 3 Aktivitas Menggunting "Kukusang"

Aktivitas selanjutnya setelah "kukusang" digunting yaitu seluruh siswa diarahkan untuk mengamati hasil pengguntingan "kukusang" tersebut dengan seksama dan siswa diarahkan untuk memberikan kesimpulan terhadap aktivitas tersebut. Pada saat proses pengamatan sedang berlangsung, terjadi percakapan antara siswa seperti yang terdapat dalam manuskrip berikut.

Guru : Bagaimana pendapat anda tentang aktivitas tersebut?

SP 1 : Oooo...iya pak, ternyata kalau "kukusangnya" digunting hasilnya jadi seperti yang di lingkaran itu.

Guru : Apa namanya jika pada lingkaran?

SP 1 : (SP 1 terdiam, kemudian menjawab), saya lupa pak namanya.

Guru : Apakah ada yang tahu, jika "kukusang” digunting dan kemudian direbahkan bentuknya seperti apa?

SP 3 : Itu namanya, (SP 3 terdiam sejenak dan menjawab), juring pak.

Guru : Apa benar bentuknya seperti juring?

SP 3 : Iya pak seperti juring.

Guru : Kenapa SP 3 mengatakan bahwa bentuknya seperti juring. Apa yang kamu ketahui tentang bentuk juring?

SP 3 : Kalau pada materi lingkaran itu pak, juring itu bentuknya hampir mirip seperti segitiga, hanya bagian bawahnya tidak lurus, tetapi seperti lingkaran begitu pak.

Kutipan wawancara di atas, menunjukkan bahwa pada aktivitas menggunting "kukusang" dan siswa diminta untuk memberikan komentar atau kesimpulan terhadap aktivitas tersebut terlihat bahwa terjadi pertukaran informasi antara siswa. Selain itu, secara tidak langsung terjadi proses interaktivitas yang dilakukan oleh siswa, sebab dalam menjawab pertanyaan yang disampaikan oleh guru, siswa menggunakan pengetahuan yang sebelumnya oleh siswa yakni konsep lingkaran lebih khususnya juring. Penggunaan konteks "kukusang" dalam pembelajaran membantu siswa dalam menemukan atau mengetahui konteks yang baru yakni jika selimut "kukusang" digunting mengikuti garis pelukis kemudian direbahkan maka hasil dari pengguntingan "kukusang" tersebut akan menjadi sebuah juring pada lingkaran.

Berdasarkan deskripsi pembelajaran yang dilaksanakan pada pertemuan pertama dapat disimpulkan bahwa penerapan pendekatan PMRI dapat meningkatkan keaktifan dan pemahaman siswa terhadap materi yang dipelajari. Penggunaan "kukusang" sebagai konteks dalam pembelajaran terbukti membuat siswa secara dapat memahami dan menemukan sendiri setiap unsur-unsur dan 
jaring-jaring yang terdapat dalam kerucut. Penemuan unsur-unsur kerucut dilakukan oleh siswa dengan cara mengamati secara seksama "kukusang" yang, dibagikan kepada setiap kelompok, kemudian diidentifikasi secara langsung oleh siswa berbagai unsur-unsur tersebut. Aktivitas tersebut memudahkan dan membantu siswa dalam proses identifikasi, karena pembelajaran yang dilaksanakan terlihat nyata dengan adanya "kukusang" tersebut. Jaring-jaring kerucut ditemukan oleh siswa melalui aktivitas membelah "kukusang." "Kukusang" sebagai benda yang memiliki bentuk menyerupai kerucut, terlebih dahulu dibuat alasnya oleh siswa dengan cara menggunting kertas yang memiliki ukuran sesuai dengan lingkaran yang terdapat pada "kukusang." Selanjutnya, siswa menggunting "kukusang" melalui garis pelukis yang dibuat sendiri oleh siswa, sehingga "kukusang" (selimut kerucut) terbuka dan berbentuk menyerupai kerucut.

\section{b. Pertemuan Kedua: Menentukan Rumus Luas Permukaan Kerucut}

Pembelajaran dilaksanakan dengan cara siswa diarahkan untuk menempelkan "kukusang" yang telah digunting pada manila karton yang berbentuk lingkaran. Pada aktivitas ini, terdapat satu kelompok (kelompok 3) yang mengalami kesulitan dalam menempelkan "kukusang" pada manila karton yang berbentuk lingkaran, sehingga tepi "kukusang" dan tepi lingkaran saling bersesuaian. Selanjutnya, guru mengarahkan siswa untuk melakukan pengamatan terhadap "kukusang" dan lingkaran kemudian melengkapi LAS 2. Aktivitas ini dilakukan dengan tujuan agar seluruh siswa dapat menemukan dan berkesimpulan bahwa "kukusang" yang ditempelkan pada lingkaran sama halnya dengan luas juring pada lingkaran.

Hasil dari aktivitas yang dilakukan oleh siswa diketahui bahwa seluruh siswa mampu menentukan atau membuat kesimpulan bahwa "kukusang" yang ditempelkan pada manila karton berbentuk lingkaran sama dengan luas juring pada lingkaran, dikarenakan pada pertemuan pertama, siswa telah menemukan bahwa jika kukusang digunting berdasarkan garis pelukis kemudian direbahkan, maka "kukusang" tersebut akan terbentuk seperti sebuah juring pada lingkaran. Hal ini secara jelas menjelaskan bahwa siswa mampu menggunakan keterkaitan antara setiap materi pembelajaran dalam matematika yang telah dimiliki atau dipelajari sebelumnya ke dalam materi selanjutnya.

Aktivitas selanjutnya yaitu guru mengarahkan siswa untuk melakukan pengukuran terhadap "kukusang" dan lingkaran kemudian dicatat pada LAS 2. Hasil pencatatan tersebut dilakukan perbandingan oleh siswa dengan tujuan siswa dapat menentukan bahwa panjang busur dari "kukusang" sama dengan keliling lingkaran kecil (alas lingkaran). Hal ini penting dilakukan agar siswa dapat mengkonstruksi sendiri pemikiran mereka dalam menemukan konsep matematika formal yaitu untuk menemukan rumus luas permukaan kerucut. Proses aktivitas siswa dalam melakukan pengukuran seperti tampak pada Gambar 4. Berdasarkan hasil pengamatan yang dilakukan pada aktivitas siswa diketahui bahwa siswa belum dapat menyimpulkan bahwa panjang busur "kukusang" sama dengan keliling lingkaran kecil. Oleh karena itu, guru mengarahkan pemikiran siswa melalui pengajuan pertanyaan sehingga diharapkan siswa dapat membuat kesimpulan yang tepat. 


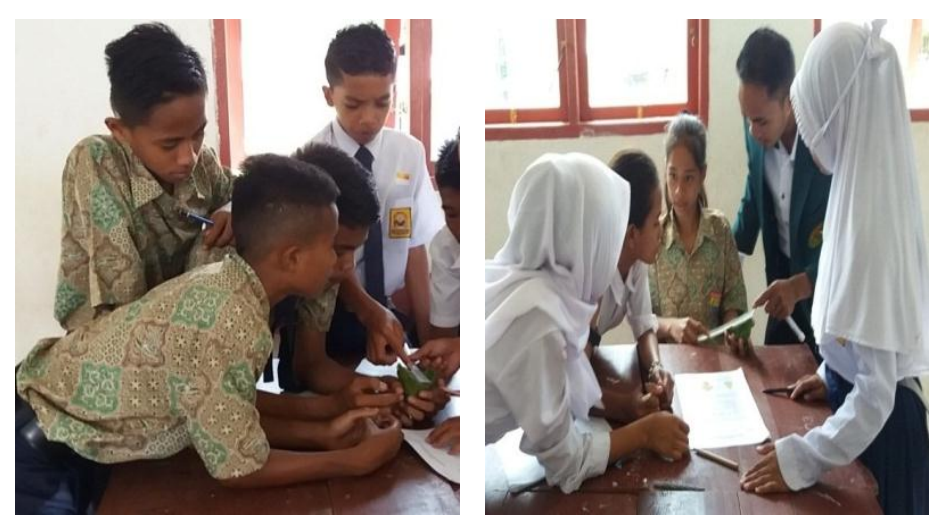

Gambar 4. Aktivitas Siswa dalam Mengukur "Kukusang"

Pada awalnya siswa mengalami kesulitan dalam menentukan ukuran dari panjang busur pada "kukusang," namun setelah diarahkan oleh guru melalui pemberian pertanyaan secara langsung siswa mulai dapat menghubungkan antara aktivitas yang pernah dilakukan sebelumnya dengan aktivitas yang sedang dilakukan. Selanjutnya, setelah siswa dipastikan telah memahami bahwa keliling lingkaran kecil sama dengan panjang busur pada "kukusang" dengan baik, maka guru mengarahkan seluruh siswa berdiskusi dengan teman kelompok untuk mengamati luas juring dan menyelesaikan pada LAS 2.
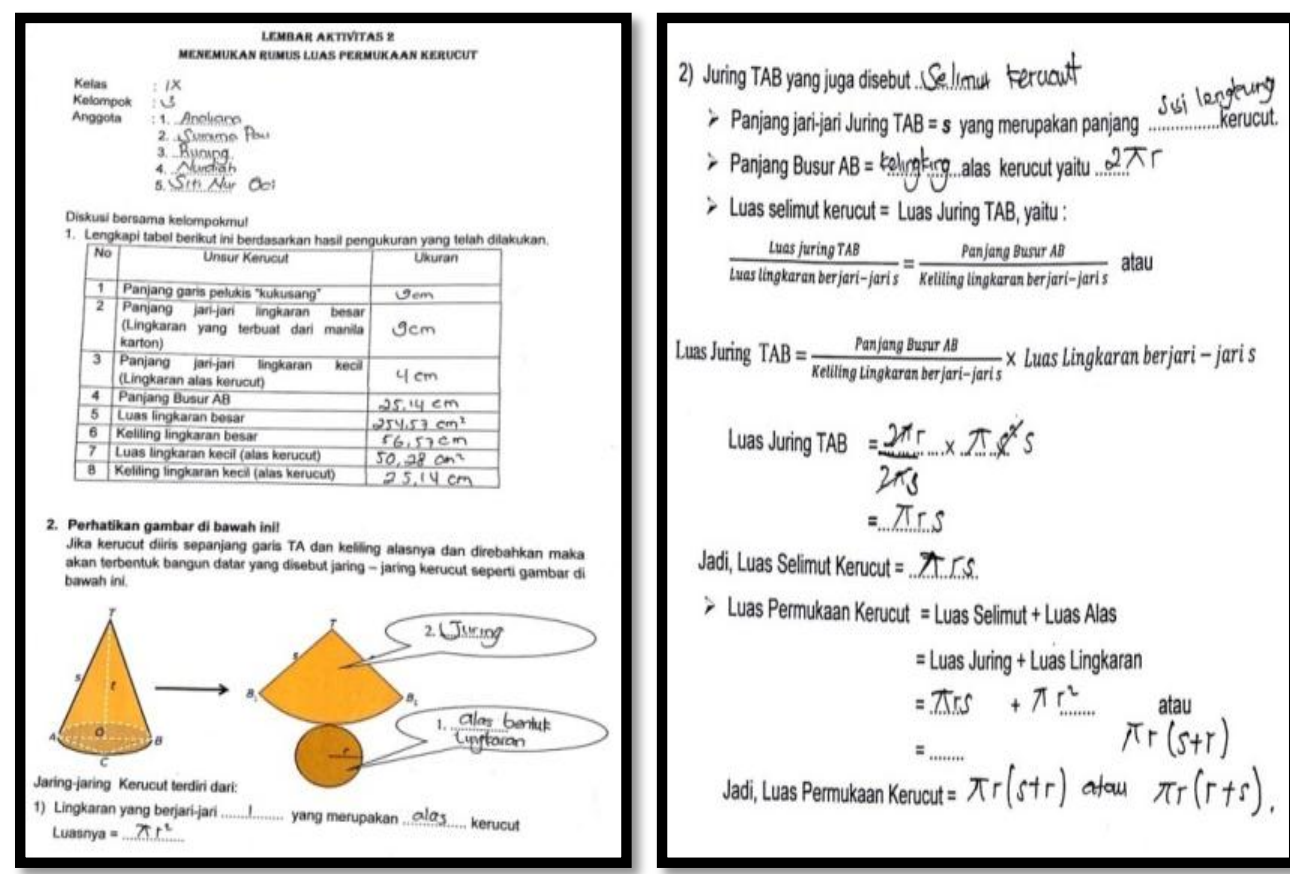

Gambar 5. Hasil Kerja Siswa pada LAS 2

Berdasarkan deskripsi pembelajaran dan hasil kerja siswa pada LAS 2 di atas, disimpulkan bahwa pembelajaran yang dilaksanakan dengan pendekatan PMRI mampu meningkatkan aktivitas siswa dalam proses pembelajaran. Sebab siswa terlibat secara langsung dalam menemukan rumus luas permukaan kerucut serta siswa mampu menghubungkan berbagai materi yang telah dipelajari sebelumnya untuk menyelesaikan permasalahan yang dihadapi siswa selama proses pembelajaran. Pembelajaran dengan pendekatan PMRI membuat siswa 
terlibat aktif dalam proses penyelesaian masalah melalui kegiatan diskusi kelompok, sehingga gabungan dari berbagai pendapat siswa mampu menghasilkan sebuah kesimpulan yang sesuai dengan tujuan pembelajaran yang akan dicapai.

\section{c. Pertemuan Ketiga: Menentukan Rumus Volum Kerucut}

Pembelajaran dilaksanakan dengan cara guru mengarahkan siswa untuk melakukan pengukuran terhadap "kukusang" dan tabung yang telah bagikan kepada siswa sebelumnya. Pengukuran tersebut meliputi tinggi "kukusang," diameter pada "kukusang," tinggi tabung, dan diameter tabung. Proses pengukuran yang dilakukan seperti tampak pada gambar berikut.
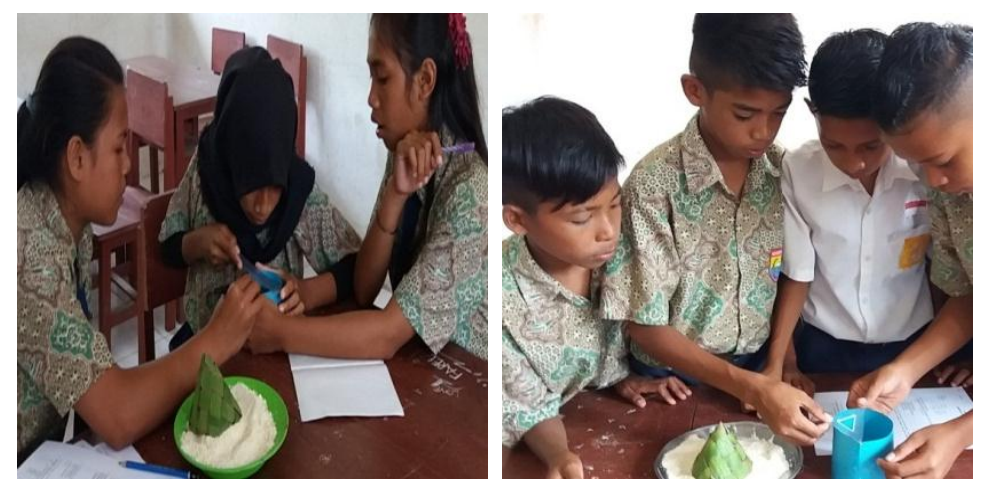

Gambar 6. Aktivitas Pengukuran pada LAS 3

Aktivitas pengukuran yang dilakukan oleh setiap kelompok terlihat bahwa siswa tidak mengalami kesulitan yang berarti dalam melakukan pengukuran tersebut. Ketika siswa telah selesai melakukan pengukuran terhadap "kukusang" dan tabung, maka guru mengarahkan pemikiran siswa melalui pemberian pertanyaan secara langsung untuk dapat menyimpulkan bahwa tinggi dan diameter pada "kukusang" dan tabung ternyata memiliki ukuran yang sama seperti yang terdapat dalam manuskrip percakapan berikut.

Guru : Apakah anda telah yakin bahwa dalam melakukan pengukuran tidak mengalami kekeliruan?

Siswa : Tidak pak guru.

SP 2 : Pak guru cara mengukurnya sama saja dengan yang belajar pertemuan kemarin kan?

Guru : Iya benar.

SP 2 : Berarti kita ukurnya sudah benar pak guru.

Guru : Baik, jika anda sudah melakukan pengukuran dengan baik dan benar. Sekarang coba anda amati dengan seksama pada LAS 3, hasil pengukuran yang telah dilakukan terhadap "kukusang" dan tabung tersebut dan apa kesimpulan yang anda peroleh?

SP 4 : Amati hasil yang mana pak guru?

Guru : Hasil pengukuran yang di LAS 3.

Siswa : Baik pak guru.

Guru : (Guru kemudian memberikan waktu \pm 2 menit kepada siswa untuk mengamati dan menyimpulkan hasil pengukuran pada LAS 3). Sudah selesai melakukan pengamatan?

Siswa : Sudah pak guru. 
Guru : Apa kesimpulan yang anda peroleh berdasarkan hasil pengukuran tersebut?

SP 1 : Ukurannya sama pak guru.

Guru : Bagian mana yang memiliki ukuran yang sama?

SP 1 : Tinggi "kukusang" dan tinggi tabung ukurannya sama-sama $9 \mathrm{~cm}$, sedangkan diameter "kukusang" dan diameter tabung sama-sama $8 \mathrm{~cm}$ pak guru.

Berdasarkan kutipan wawancara di atas, diketahui bahwa aktivitas pengukuran pada "kukusang" dan tabung dapat dilakukan dengan baik oleh siswa pada setiap kelompok. Selain itu, siswa mampu membuat kesimpulan bahwa "kukusang" dan tabung yang digunakan dalam proses pembelajaran memiliki ukuran tinggi dan diameter yang sama. Aktivitas selanjutnya, guru meminta seluruh siswa bekerja sama dengan teman kelompoknya untuk memasukkan "kagepe" ke dalam tabung hingga penuh, kemudian "kagepe" tersebut kembali dituangkan ke dalam kerucut sehingga "kagepe" yang terdapat di dalam tabung habis. Selanjutnya, siswa diarahkan untuk menyelesaikan LAS 3 seperti tampak pada gambar berikut ini.

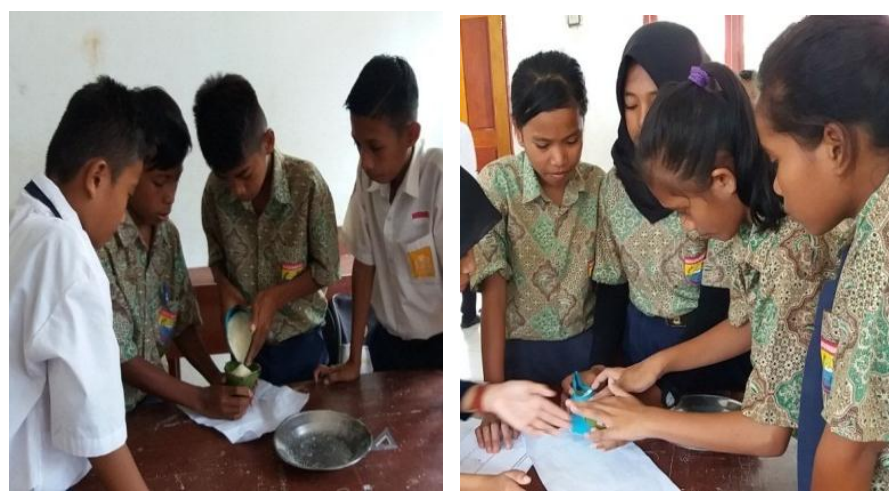

Gambar 7. Aktivitas Siswa

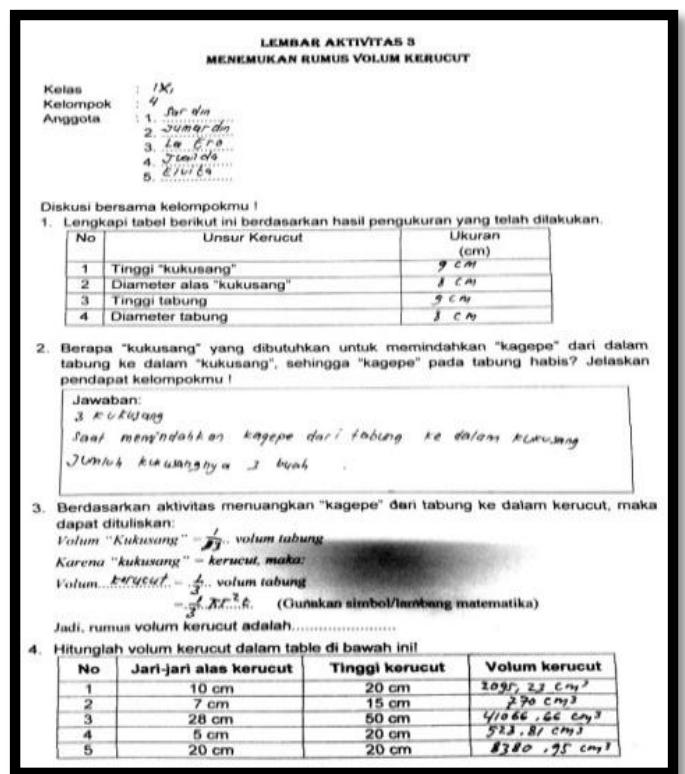

Gambar 8. Hasil Kerja Siswa pada LAS 3 
Berdasarkan proses aktivitas dan hasil kerja siswa dalam menyelesaikan LAS 3 diketahui bahwa proses menemukan rumus volum kerucut mampu dilakukan oleh siswa dengan baik. Siswa mampu mengkonstruksi pemikiran mereka sendiri melalui kegiatan diskusi dan pertukaran informasi hal yang sifatnya kontekstual menuju proses matematika formal. Hal ini secara jelas menggambarkan bahwa pembelajaran dengan pendekatan PMRI yang menempatkan siswa sebagai subjek dalam pembelajaran mampu mengembangkan kemampuan proses berpikir siswa dalam proses penyelesaian masalah yang dialami dalam proses pembelajaran.

\section{Hasil Analisis Subjek Penelitian \\ a. Analisis SP 1}

Berdasarkan hasil analisis pada SP 1 pada penyelesaian soal kemampuan pemecahan masalah dapat disimpulkan bahwa penerapan pendekatan PMRI dapat mengembangkan dan meningkatkan kemampuan SP 1 dalam proses pemecahan masalah. Hal tersebut terlihat dari proses penyelesaian SP 1 dalam menyelesaikan soal kuis 2 dan 3 serta soal evaluasi akhir kemampuan pemecahan masalah. Penyelesaian soal yang dilakukan sesuai dengan tahapan pemecahan masalah yang digunakan dalam penelitian ini. SP 1 dapat menggunakan berbagai keterkaitan antara materi matematika dalam penyelesaian tersebut, seperti menggunakan teorema phytagoras dan konsep perbandingan. Hal ini menunjukkan bahwa proses berpikir SP 1 tidak terbatas pada penggunaan materi kerucut untuk menyelesaikan soal pemecahan masalah. Adapun berbagai kekurangan yang dimiliki SP 1 adalah dalam menyelesaikan soal evaluasi nomor 2 tidak mampu diselesaikan dengan baik oleh SP 1 disebabkan karena kekeliruan dalam menafsirkan maksud dari soal evaluasi tersebut, serta keterbatasan waktu dalam proses penyelesaian soal sehingga mengakibatkan sebagian tahapan penyelesaian masalah tidak dilakukan dengan baik oleh SP 1 .

\section{b. Analisis SP 2}

Berdasarkan hasil analisis pada penyelesaian soal oleh SP 2, dapat disimpulkan bahwa penerapan pendekatan PMRI dalam pembelajaran luas permukaan dan volum kerucut dapat meningkatkan kemampuan SP 2 dalam pemecahan masalah. Hal ini terlihat dari hasil penyelesaian soal kemampuan pemecahan masalah yang dikerjakan oleh SP 2, yakni dalam penyelesaian soal tersebut SP 2 dapat menuliskan berbagai tahapan pemecahan masalah. Penyelesaian soal oleh SP 2 selalu didahului dengan memahami masalah kemudian menuliskan setiap unsur yang diketahui dan ditanyakan dalam soal tersebut dan dilanjutkan dengan merumuskan strategi yang akan digunakan dalam penyelesaian tersebut. Pada tahapan penyelesaian, SP 2 selain menggunakan materi luas permukaan dan volum kerucut yang telah dipelajari sebelumnya, SP 2 juga dapat menggunakan berbagai keterkaitan antara materi matematika sehingga memungkinkan SP 2 dalam menyelesaikan soal dengan tepat. Tahapan akhir yang dilakukan oleh SP 2 adalah melakukan pengecekan kembali jawaban yang telah diperoleh pada tahapan penyelesaian untuk memastikan kebenaran atas jawaban yang diperoleh dalam penyelesaian soal pemecahan masalah.

\section{c. Analisis SP 3}

Berdasarkan hasil kerja SP 3 dalam menyelesaikan soal pemecahan masalah yakni soal kuis dan soal evaluasi dapat disimpulkan bahwa SP 3 
memiliki kemampuan pemecahan dan proses berpikir yang baik. Hal ini terlihat dari hasil kerja SP 3 dalam menyelesaikan soal yang secara keseluruhan diawali dengan tahapan memahami masalah kemudian merumuskan strategi yang akan digunakan dalam proses penyelesaian tersebut. SP 3 dalam merumuskan strategi dilakukan dengan menuliskan berbagai tahapan yang perlu dilakukan dalam menyelesaikan soal pemecahan masalah, hal ini memungkinkan SP 3 untuk menghindari kekeliruan dan mempermudah SP 3 dalam proses pemecahan masalah. Selain itu, SP 3 mampu menggunakan keterkaitan antara materi matematika seperti menggunakan konsep teorema phytagoras, konsep perbandingan, dan sebagainya, serta menggunakan pola gambar untuk menganalisis proses penyelesaian soal. Hal ini menunjukkan bahwa kemampuan pemahaman dan daya ingat SP 3 terhadap materi matematika cukup baik, sehingga SP 3 dapat menyelesaikan soal pemecahan masalah dengan tepat. Kekurangan yang terdapat pada SP 3 adalah dalam penyelesaian soal tersebut SP 3 tidak melakukan pemeriksaan kembali atas jawaban yang diperoleh dalam setiap penyelesaian soal dikarenakan keterbatasan waktu dalam menyelesaikan soal. Selain itu, SP 3 tidak dapat menyelesaikan soal evaluasi akhir nomor 2 dengan baik disebabkan karena kekeliruan dalam menafsirkan maksud dari soal evaluasi tersebut..

\section{d. Analisis SP 4}

Berdasarkan hasil kerja SP 4 di atas, terhadap penyelesaian soal pemecahan masalah dapat disimpulkan bahwa SP 4 memiliki proses berpikir kemampuan pemecahan masalah yang baik. Hal ini terlihat dari penyelesaian soal yang dilakukan oleh SP 4 yaitu mampu menyelesaikan soal dengan menggunakan tahapan pemecahan masalah. Penyelesaian yang dilakukan oleh SP 4 diawali dengan cara memahami masalah yang terdapat pada soal dengan baik, kemudian menuliskan berbagai unsur yang diketahui dalam soal serta merumuskan berbagai strategi atau tahapan yang akan dilakukan untuk melakukan penyelesaian terhadap soal pemecahan masalah. Selanjutnya, dengan berpedoman pada strategi yang telah dirumuskan SP 4 melakukan penyelesaian terhadap soal tersebut dengan cara menggunakan konsep matematika yang telah dimiliki sebelumnya oleh SP 4 . Hal ini menunjukkan bahwa tingkat pemahaman yang dimiliki oleh SP 4 cukup baik, sehingga mampu untuk menganalisis serta melakukan proses penyelesaian masalah. Setelah memperoleh jawaban atas penyelesaian soal tersebut, SP 4 kemudian melakukan pemeriksaan kembali atas jawaban yang diperoleh dalam proses penyelesaiannya.

Kekurangan yang terdapat dalam proses penyelesaian soal oleh SP 4 adalah terdapat soal yang tidak dikerjakan oleh SP 4 secara keseluruhan, sehingga tidak memperoleh jawaban akhir berdasarkan konteks pertanyaan pada soal. Hal ini dikarenakan penggunaan waktu yang terlalu lama oleh SP 4 di tahap awal penyelesaian yakni pada tahapan penyelesaian, sehingga mengakibatkan pertanyaan pada bagian selanjutnya tidak dapat dikerjakan dengan maksimal.

\section{e. Analisis SP 5}

Berdasarkan hasil kerja SP 5 dalam menyelesaikan soal evaluasi pemecahan masalah dapat disimpulkan bahwa SP 5 memiliki kemampuan pemecahan masalah yang belum maksimal. Sebab, pada setiap hasil penyelesaian soal yang dilakukan SP 5 tidak melakukan pemeriksaan kembali atas jawaban yang diperoleh. Hal tersebut selain dikarenakan keterbatasan waktu yang dimiliki 
saat penyelesaian soal, juga keterbatasan pemahaman terhadap materi matematika yang lain sehingga membutuhkan waktu yang relatif lama ketika menyelesaikan soal pemecahan masalah. Meskipun memiliki kemampuan pemecahan masalah yang belum maksimal, namun SP 5 termasuk siswa yang memiliki proses berpikir yang baik, terlihat dari alasan pembulatan bilangan yang dilakukan SP 5 pada proses penyelesaian soal dan disesuaikan dengan konteks dunia nyata. Hal tersebut menggambarkan bahwa SP 5 dalam menyelesaikan soal tidak hanya berfokus pada konteks soal, namun juga dikaitkan dengan kondisi nyata pada kehidupan sehari-hari.

\section{SIMPULAN DAN SARAN}

Hasil analisis retrospektif dan analisis data terhadap kemampuan pemecahan masalah matematis siswa dalam menyelesaikan soal luas permukaan dan volum kerucut dapat disimpulkan bahwa penerapan pendekatan Pendidikan Matematika Realistik Indonesia (PMRI) mampu mengembangkan dan meningkatkan kemampuan pemecahan masalah matematis siswa dalam proses pembelajaran dan penyelesaian masalah.

Penggunaan konteks mampu merubah paradigma berpikir siswa bahwa dunia nyata bukan hanya sekedar tempat pengaplikasian konsep yang telah dipelajari, melainkan dengan menggunakan konteks dalam pembelajaran membentuk pola berpikir siswa bahwa pembelajaran matematika berasal dari aktivitas manusia sehari-hari menuju matematika formal kemudian diaplikasikan kembali dalam proses pemecahan masalah.

Aktivitas dengan menggunakan konteks "kukusang" membuat siswa terlibat langsung dalam melakukan berbagai kegiatan yang diarahkan oleh guru dalam menemukan konsep unsur-unsur dan jaring-jaring kerucut, serta rumus luas pemukaan kerucut dengan menggunakan pemahaman matematika yang telah dimiliki sebelumnya oleh siswa terkait konsep lingkaran. Konteks "kagepe" digunakan dalam pembelajaran untuk menemukan rumus luas volum kerucut. Pada pembelajaran siswa diarahkan untuk mengisi "kagepe" ke dalam tabung yang memiliki diameter dan tinggi yang sama dengan kerucut, kemudian diisi kembali ke dalam "kukusang." Melalui aktivitas tersebut siswa dapat menemukan rumus volum kerucut yang dengan menggunakan bantuan pemahaman yang telah dimiliki sebelumnya oleh siswa tentang konsep volum tabung.

Pemanfaatan hasil konstruksi siswa berperan dalam mengembangkan kemampuan pemahaman terhadap materi yang dipelajari dan kemampuan pemecahan masalah matematis siswa. Interaktivitas yang terbentuk tidak hanya antara guru dengan siswa, melainkan juga antara siswa dengan siswa melalui kegiatan diskusi maupun penyelesaian soal pemecahan maslah secara berkelompok serta kegiatan tanya jawab yang dilakukan secara langsung ketika pembelajaran berlangsung. Keterkaitan (intertwinement) dalam pembelajaran materi luas permukaan dan volum kerucut yaitu penggunaan konsep yang telah dimiliki sebelumnya yakni pada konsep lingkaran, teorema phytagoras, perbandingan, maupun aritmetika sosial, serta kemampuan untuk menggunakan pola gambar untuk menjelaskan pola penyelesaian masalah berupa soal non-rutin. 


\section{DAFTAR RUJUKAN}

Abidin, Z. (2015). Intuisi dalam Pembelajaran Matematika; Konstruksi Pemecahan Masalah Divergen dengan Gaya Kognitif Field Independent dan Field Dependent. Jakarta: Lentera Ilmu Cendekia.

Bakker, A. (2004). Design Research in Statistics Education: On Symbolizing and Computer Tools. (Online), http://www.fi.uu.nl/publicaties/literatur/6274. (Diakses Selasa. 11 Oktober 2016 Pkl. 21.00 WIB).

Floyd, N. C. (2002). Problem Solving Strategies in Mathematics. Lesson Plan Project-Educ 6304.Volume. 15. No. 2. p.68-74.

Gravemeijer. K. (1994). Developing Realistic Mathematic Education. Utrecht: Freudenthal Institute.

Hasanah. (2016). "Keefektifan Pembelajaran Murder Berpendakatan PMRI dengan Asesmen Kinerja pada Pencapaian Kemampuan Literasi Matematika Siswa SMP Serupa PISA." UNNES Journal of Mathematics Education. pISSN 2252-6927, (Online), http://journal.unnes.ac.id/sju/index.php/ujme. (Diakses Rabu, 12 Oktober 2016 Pkl. 09.15 WIB).

Lestari, K. E \& Yudhanegara, M. R. (2015). Penelitian Pendidikan Matematika. Bandung: Refika Aditama.

Maslihah, S. (2012). Pendekatan Matematika Realistik Sebagai Pendekatan Belajar Matematika. Jurnal Phenomenon. Volum. 2 Nomor. 1, Hal. 109122. Semarang: IAIN Walisongo.

Nurshanti. (2016). Design Research: Penerapan Pendekatan PMRI dengan Model $\checkmark$ Pembelajaran STAD pada Pembelajaran Luas Permukaan dan Volum Kubus dan Balok untuk Mengembangkan Kemampuan Pemecahan Masalah Matematis di Kelas VIII SMP Negeri 121 Jakarta." Tesis tidak Diterbitkan. Jakarta: UNJ

Polya. G. (1973). How to Solve it. New Jersey: Princeton University Press.

Turmudi. (2008). Landasan Filsafat dan Teori Pembelajaran Matematika (Paradigma Eksploratif dan Investigatif. Jakarta: Leuser Cita Pustaka.

Van den Akker. J. et al. (2006). Introducing Educational Design Research. New York: Routledge

Wardhani S. (2008). Analisis SI dan SKL untuk Mata Pelajaran Matematika SMP/MTs untuk Optimalisasi Tujuan Mata Pelajaran Matematika. Jogyakarta: PPPPTK Matematika

, (2010). Pembelajaran Kemampuan Pemecahan Masalah di SMP. Yogyakarta: PPPPTK.

Zulkardi, dkk. (2001). Realistic Mathematics Education (RME): Teori. Contoh Pembelajaran dan Taman Belajar di Internet. dalam Seminar Sehari Realistic Mathematics Education. Makalah pada seminar sehari RME di Jurusan Pendidikan Matematika UPI Bandung pada tanggal 4 April 2001. Bandung: UPI.

Zulkardi, Evy Yosita Silva, dan Darmawijoyo. (2011). Pengembangan Soal Matematika Model PISA pada Konten Uncertainty untuk Mengukur Kemampuan Pemecahan Masalah Matematika Siswa Sekolah Menengah Pertama. Jurnal Pendidikan Matematika, 5 (1). Pp. 1-11. 